\title{
DEPREM BÖLGESINDEKİ BAZI ÜLKELERDE EŞDEĞER DEPREM YÜKÜ METODUNUN KARŞILAŞTIRILMASI
}

\author{
${ }^{1}$ Mehmet UZUN, ${ }^{2}$ Hasan Hüsnü KORKMAZ \\ ${ }^{1}$ Selçuk Üniversitesi, Mühendislik Fakültesi, İnşaat Mühendisliği Bölümü, KONYA \\ ${ }^{2}$ Selçuk Üniversitesi, Mühendislik Fakültesi, İnşaat Mühendisliği Bölümü, KONYA \\ 1mehmetuzun@selcuk.edu.tr, 2hhk73@selcuk.edu.tr
}

(Geliş/Received: 16.01.2018; Kabul/Accepted in Revised Form: 05.10.2018)

ÖZ: Deprem hareketinin yapılar üzerinde yıkıcı bir etkisi bulunmaktadır. Bu etkinin yapıların tasarımı sırasında gerçeğe en yakın şekli ile hesap edilmesi ve tasarımın buna göre yapılması toplumun can güvenliği açısından çok büyük önem arz etmektedir.

Deprem hareketinin yapıya etkisinin hesaplanması için birçok metot bulunmaktadır. Bu metotlar içerisinde en sade, en anlaşılır ve uygulaması en kolay olan metot Eş Değer Deprem Yükü Metodudur. Eş Değer Deprem Yükü Metodu genel olarak yapıya deprem esnasında etki edecek yatay yükün belirli katsayılar yardımı ile hesaplanmasına dayanmaktadır. Yapıların deprem sırasındaki karmaşık davranışını basite indirgemek için kullanılan bazı katsayılar geliştirilmiştir. Kullanılan katsayılar her ülke için değişmektedir.

$\mathrm{Bu}$ çalışmada ülkemiz yönetmeliğinde yer alan Eş Değer Deprem Yükü Metodunun farklı ülkelerdeki Eş Değer Deprem Yükü Metotları ile kıyaslanması yapılmıştır. Yapılan çalışmada 6 katlı betonarme bir yapı ele alınmıştır. Yapının x ve y yönlerinde 2 açıklı̆̆ı bulunmaktadır. Yapının ağırlığı ve bilinen bazı özellikleri kullanılarak ETABS programında üç boyutlu modeli oluşturulmuştur. Yapının doğal titreşim periyodu programdan alınarak yapıya etki edecek taban kesme kuvvetleri hesaplanarak karşılaştırılmıştır.

Anahtar Kelimeler: Deprem yönetmelikleri, Eş değer deprem yükü metodu, Sonlu elemanlar metodu, Taban kesme kuvveti, TDY - 2007.

\section{Comparison of Equivalent Earthquake Methods in some Countries in Earthquake Zone}

ABSTRACT: Earthquakes have detrimental effects on the structures. The loads due to earthquakes must be correctly determined and structural analysis and designs must be performed according to that predicted lateral loads.

For the representation of lateral seismic forces on the structures, several methods are available. The simplest method among them is the "equivalent lateral load method". This method depends on the calculation of lateral load that acts to the structure during seismic activity by multiplying the weight with some variable constants. Several constants are developed to represent complex behavior. These variable constants are changing for every countries code or regulation.

In this study, equivalent earthquake load method defined in Turkish Earthquake Code is compared with the regulations on different countries code. A 6-storey reinforced concrete structure is considered in the study. There are 2 spans in the $x$ and $y$ directions of the build. Three-dimensional model is created in the ETABS program using the weight of the structure and some known features. The natural vibration period of the structure is taken from the program and the base shear forces acting on the structure are calculated and compared. 
Key Words: Base shear, Equivalent earthquake force method, Finite element method, Seismic codes, TEC-2007.

\section{GİRIŞ (INTRODUCTION)}

Dünyadaki en yoğun deprem kuşaklarl; yeryüzündeki depremlerin \%81'ininin oluştuğu Pasifik Deprem Kuşağı, \%17'sinin oluştuğu Alp-Himalaya Deprem Kuşağı'dır. Türkiye ise bu deprem kuşaklarından Alp-Himalaya Deprem Kuşağı'nda yer almasından dolayı Dünyada depremselliği en yüksek olan ülkelerden birisidir. Deprem Bölgeleri Haritası'na göre, yurdumuzun \%92'sinin deprem bölgeleri içerisinde olduğu, nüfusumuzun \%95'inin deprem tehlikesi altında yaşadığı ve ayrıca büyük sanayi merkezlerinin \%98'i ve barajlarımızın \%93'ünün deprem bölgesinde bulunduğu bilinmektedir (Ünal, 2012).

Deprem hareketi temelde harmonik bir dalga yayılımı olduğu için kuvvete dönüştürülmesi zordur. En basit hali ile depremin yapı üzerine etki eden bir ivme olduğu düşünülürse yapıda oluşturacağı etkiler bu ivmenin oluşturacağı eylemsizlik momenti ile hesaplanabilmektedir. Yapıya etki edecek bu ivmenin hesaplanması ise çok karmaşık bir konudur. Bu nedenle deprem kuvvetinin hesaplanması için birçok farklı metot ortaya çıkmıştır. Ülkemizde ve birçok farklı ülkede kabul görmüş ve yönetmeliklerde kullanılmasına müsaade edilen yöntemler Eşdeğer Deprem Yükü Metodu, Mod Birleştirme Metodu, Zaman Tanım Alanında Analiz Metodudur.

Eşdeğer Deprem Yükü Metodu bu metotlar içerisinde en kolay anlaşılır ve en kolay uygulanabilir olanıdır. Bu metodun temelinde yapının deprem altındaki davranışını etkileyen parametrelerin hesaba alınırken birer katsayı olarak değerlendirilmesi yatar. Kullanılacak bu katsayılar bazı özelliklere dayanmaktadır:

a. Yapının ülke içerisindeki fay hatlarına olan uzaklığına

b. Yapının yapılacağ 1 zeminin türüne

c. Yapıda kullanılacak taşıyıcı sistem türüne

d. Yapılacak yapının kullanım amacına

e. Yapının doğal titreşim periyoduna

Bu etkileri göz önüne almak için kullanılacak katsayıların değerleri çok büyük önem arz etmektedir. Alınacak değerler gerçekten uzaklaştıkça yapıya etki edeceğini düşünülen deprem kuvveti de gerçekten uzak değerler alacaktır. Gerçek değerden uzaklaşırken deprem kuvvetinin çok fazla artırılması yapıda taşıyıcı sistem elemanlarının kesitlerini artıracaktır. Kesitlerin artması malzeme kullanımını artırarak yapı maliyetlerinde gereksiz yere bir artışa neden olacaktır. Tam tersi düşünülecek olursa katsayıların yanlış alınmasından dolayı yapıya etki edecek deprem kuvveti gerçekten düşük hesaplanırsa deprem esnasında yeterli davranışı gösteremeyecek bir yapı ortaya çıkmış olacaktır.

Farklı birçok ülkede kullanılan Eşdeğer Deprem Yükü Metodu'nda katsayılarda ülke ülke değişmektedir. Alınan bu farklı katsayılar hesap edilen deprem kuvvetini de değiştirmektedir. Yapılan bu çalışmada ülkemizde alınan katsayıların diğer ülkeler düşünüldüğünde ne kadar güvenli tarafta kaldığ ya da ne kadar yetersiz olduğu araştırılmıştır.

Tekince (2015) yaptığı çalışmada EC - 8 ve DBYBHY - 2007 yönetmeliklerine göre farklı taşıyıcı sistemlere sahip binaların yönetmeliklerde verilen Eşdeğer Deprem Yükü Metodu ve Mod Birleştirme Metodlarına göre karşılaştırmaları yapılmıştır. Bu çalışmada farklı zemin türleri, farklı kat sayıları, farklı beton sınıfları dikkate alınarak hesap yapılmıştır. Çalışma sonucunda elde edilen bulgulara göre Eşdeğer Deprem Yükü Metodu ile yapılan çözümler de elde edilen taban kesme kuvvetleri, göreli kat ötelemeleri, maksimum yer değiştirmeler, kirişlerde oluşan maksimum kesme kuvvetleri ve momentler daima Mod Birleştirme Metoduna göre büyük çıkmıştır. Ayrıca DBYBHY - 2007' de Eşdeğer Deprem Yükü Metoduna göre yapılan analiz sonucunda elde edilen taban kesme kuvvetleri EC -8 ' de elde edilen taban kesme kuvvetinden daha büyük çıkmıştır. 
Taşkın (2012) yaptığı çalışmada EC - 8, ASCE - 7 ve DBYBHY - 2007 yönetmeliklerine göre 12 kattan oluşan betonarme bir yapıyı hem Eşdeğer Deprem Yükü Metodu ile hem de Mod Birleştirme Metodu ile çözmüştür. Yapılan çözümde Sap2000 V15 programı kullanılmıştır. Yapıların bulundukları ülkelerde depremin en yıkıcı etkiyi oluşturduğu bölgede oldukları kabul edilmiştir. Yapılan çalışma sonucunda ise en elverişsiz durumların EC -8 yönetmeliğine göre elde edildiği en düşük kesit tesirlerinin ise DBYBHY - 2007 yönetmeliğinde elde edildiği ortaya konulmuştur. Ayrıca EC - 8 ve ASCE - 7 yönetmeliklerinde yük kombinasyonları birbirine yakın katsayılar içerdiği için kesit tesirleri de oldukça birbirine yakın çıkmıştır.

Naimi (2010) yaptığı çalışmada İran deprem yönetmeliği ve DBYBHY - 2007 yönetmeliğine göre 5 katlı ve 10 katlı betonarme perdeli binalarda Eşdeğer Deprem Yükü Metodunu kullanarak analizler yapmıştır. Sap2000 programı kullanılarak yapıda oluşan yer değiştirmeler, eğilme momentleri, taban kesme kuvvetleri ve normal kuvvet sonuçları elde edilmiştir. Bunlar ise iki yönetmelik için ayrı ayrı kıyaslanmıştır. Sonuçlar incelendiğinde ise DBYBHY - 2007 koşullarına göre elde edilen kesit tesirleri İran yönetmeliğine göre daha büyük çıkmaktadır.

Bu çalışmada, 6 farklı ülkenin deprem yönetmelikleri "Eşdeğer Deprem Yükü Yöntemi" açısından incelenmiştir. Çalışmada 6 katlı betonarme bir bina modeli oluşturulmuştur. Binanın x ve y yönünde 2 açıklı̆̆ 1 vardır. Binaya mevcut döşemelerden ve kolon ve kiriş sisteminden gelen yükler haricinde, kirişler üzerinde duvar yükü, döşemeler üzerinde ise hareketli yük ve kaplama yükleri tanımlanmıştır. Yapının modeli ETABS programında hazırlanarak depreme esas ağırlığı ve doğal titreşim periyodu programdan alınmıştır. Elde edilen veriler ile her yönetmelik için yapıya etki etmesi beklenen deprem yükü hesaplanmıştır.

\section{MATERYAL VE YÖNTEM (MATERIAL AND METHOD)}

Bu çalışmada farklı ülkelere ait deprem yönetmeliklerinde bulunan eşdeğer deprem yükü metotlarının karşılaştırması yapılmıştır. Çalışma için 6 farklı ülkeye ait deprem yönetmeliği incelenmiştir.

\section{Hindistan Deprem Yönetmeliği (Criteria For Earthquake Resistant Design Of Structures - IS 1893 )}

Depremde etki eden yatay yük yapının deprem hesabına esas bina ağırlı̆̆ı ile bir katsayının çarpılması sonucu bulunmaktadır. Taban kesme kuvveti Eşitlik 1 formülü ile hesaplanmaktadır.

$V_{B}=A_{h} \cdot W$

$V_{B}$ :Toplam taban kesme kuvveti

$A_{h}:$ Tasarım deprem yükü katsayısı

$W$ : Deprem hesabına esas yapı ağırlığ 1

Eşdeğer Deprem Yükü' nün hesaplanması için $A_{h}$ katsayısının Eşitlik 2 formülü yardımıyla hesaplanmasi gerekmektedir.

$A_{h}=\frac{Z \cdot I \cdot S_{a}}{2 \cdot R \cdot g}$

$A_{h}$ : Tasarım deprem yükü katsayısı

$Z$ : Deprem bölgesi katsayısı (Çizelge 2)

$I$ : Bina önem katsayısı (Çizelge 3)

$S_{a} / g$ :Ortalama bina ivme katsayis1

$R$ :Yapının deprem hasar performansına bağlı olarak seçilen deprem yükü azaltma katsayısıdır. Yapının gevrek ya da sünek olmasına bağlı olarak belirlenir. (Çizelge 4) 


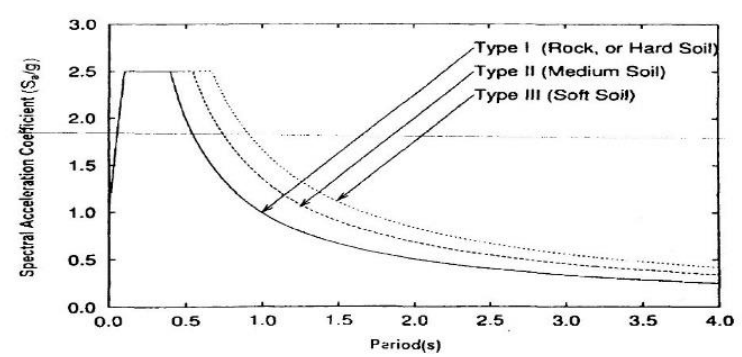

Şekil 1. Spektrum eğrisi (IS 1893)

Figure 1. Spectrum graphic (IS 1893)

$S_{a} / g$ oranı Şekil $1^{\prime}$ deki grafik yardımı ile veya Eşitlik 3,4 ve 5 . formülleri ile hesaplanabilmektedir:

$$
\begin{aligned}
& \frac{s_{a}}{g}=\left\{\begin{array}{cc}
1+15 T & 0,00 \leq T \leq 0,10 \\
2,50 & 0,10 \leq \mathrm{T} \leq 0,40 \\
1,00 / T & 0,40 \leq T \leq 4,00
\end{array}\right. \text { (Tip 1 zemini için) (IS 1893) } \\
& \frac{s_{a}}{g}=\left\{\begin{array}{cc}
1+15 T & 0,00 \leq T \leq 0,10 \\
2,50 & 0,10 \leq \mathrm{T} \leq 0,55 \\
1,36 / T & 0,55 \leq T \leq 4,00
\end{array}\right. \text { (Tip 2 zemini için) (IS 1893) } \\
& \frac{s_{a}}{g}=\left\{\begin{array}{cc}
1+15 T & 0,00 \leq T \leq 0,10 \\
2,50 & 0,10 \leq \mathrm{T} \leq 0,67 \\
1,67 / T & 0,67 \leq T \leq 4,00
\end{array}\right. \text { (Tip 3 zemini için) (IS 1893) }
\end{aligned}
$$

Doğal titreşim periyodu yapının kendi titreşimini ifade eder. Bu periyodun hesaplanması için mevcut yapıya bir titreşim verilerek doğal titreşim periyodu hesaplanabilir. Ancak mevcutta olmayan bir yapının doğal titreşim periyodunu hesaplamak için geliştirilmiş bazı formüller mevcuttur. Hindistan yönetmeliğinde tuğla duvarsız betonarme çerçeve için kabul edilen formül Eşitlik 6' da verilmiştir.

$T_{a}=0,075 \cdot h^{0,75}$

$T_{a}:$ Doğal titreşim periyodu (s)

$h:$ Bina toplam yüksekliği (m)

Yukarıda verilen formüllerde kullanılacak katsayılar Çizelge 1, 2, 3 ve 4'te verilmiştir:

Çizelge 1. Zemin Sınıfları (IS 1893)

Table 1. Soil classes (IS 1893)

\begin{tabular}{|c|c|}
\hline ZEMİN TÜRÜ & AÇIKLAMA \\
\hline Tip 1 & Kaya ve sert zeminler $(\mathrm{N}>30)$ \\
\hline Tip 2 & Orta zeminler $(10 \leq \mathrm{N} \leq 30)$ \\
\hline Tip 3 & Yumuşak zeminler $(10>\mathrm{N})$ \\
\hline
\end{tabular}

N:SPT değeri

Çizelge 2. Deprem bölgesi katsayısı (IS 1893)

Table 2. Seismic zone factors (IS 1893)

\begin{tabular}{|c|c|c|c|c|}
\hline DEPREM BÖLGESI & II & III & IV & V \\
\hline DEPREM YOĞUNLUĞU & Seyrek & Orta & Yoğun & Aşırı yoğun \\
\hline $\mathbf{Z}$ & 0,10 & 0,16 & 0,24 & 0,36 \\
\hline
\end{tabular}


Çizelge 3. Bina önem katsayıları (IS 1893)

Table 3. Building importance factors (IS 1893)

\begin{tabular}{|c|c|c|}
\hline SIRA NO & \multicolumn{1}{|c|}{ YAPI TÜRÜ } & KATSAYI \\
\hline 1 & $\begin{array}{l}\text { Önemli hizmet binaları ve hastane, okul gibi kamu binaları; } \\
\text { acil durum binaları, televizyon istasyonları, radyo istasyonları, } \\
\text { tren yolu istasyonları, sinemalar gibi büyük yı̆̆ılmaların olduğu } \\
\text { salonlar }\end{array}$ & 1,5 \\
\hline 2 & \multicolumn{1}{|c|}{ Diğer bütün binalar } & 1,0 \\
\hline
\end{tabular}

Çizelge 4. Taşıyıcı sistem davranış katsayısı (IS 1893)

Table 4. Structural system behaviour factors (IS 1893)

\begin{tabular}{|c|c|c|}
\hline SIRA NO & TAŞIYICI SİSTEM TÜRÜ & R \\
\hline 1 & Normal betonarme eğilmeye çalışan çerçeve sistem (OMRF) & 3,0 \\
\hline 2 & Özel betonarme eğilmeye çalışan çerçeve sistem (SMRF) & 5,0 \\
\hline 3 & Normal betonarme perdeli sistem & 3,0 \\
\hline 4 & Sünek betonarme perdeli sistem & 4,0 \\
\hline 5 & Normal perdeli OMRF karma sistem & 3,0 \\
\hline 6 & Normal perdeli SMRF karma sistem & 4,0 \\
\hline 7 & Sünek perdeli OMRF karma sistem & 4,5 \\
\hline
\end{tabular}

Yeni Zelanda Deprem Yönetmeliği (General Structural Design Loadings For Buildings - NZS 4203:1992)

Yapıya depremden dolayı etki edecek taban kesme kuvveti yapının deprem hesabına esas olan ağırlığının tasarım deprem yükü katsayısı ile çapılması sonucu bulunur (Eşitlik 7).

$V=W_{t} \cdot C$

$V$ :Toplam taban kesme kuvveti

$W_{t}$ : Deprem hesabına esas yapı ağırlı̆̆1

$C$ : Tasarım deprem yükü katsayısı

Deprem yükünün Eşdeğer Deprem Yükü Metodu ile hesaplanabilmesi için gerekli olan tasarım deprem yükü katsayısı ile ilgili formüller Eşitlik 8 ve 9' da verilmiştir.

$C=C_{b}\left(T_{1}, \mu\right) \cdot R \cdot Z \cdot L_{u} T_{1}>0,4$

$C=C_{b}(0.4, \mu) \cdot R \cdot Z \cdot L_{u} T_{1} \leq 0,4$

$\mathrm{C}:$ Tasarım deprem yükü katsayısı

$Z$ : Deprem bölgesi katsayısı

$\mathrm{C}_{b}$ :Ortalama bina ivme katsayısı (Çizelge 5)

$R$ :Yapının risk durumu (Yapı türüne bağlı olarak Çizelge' den seçilir.)

$\mu$ :Süneklik katsayısı (Yapının taşıyıcı sistem türüne göre Çizelge 8'den seçilir.)

$L_{u}$ : Sınır durum katsayısı (Servis yüklerinin aşılması durumunda 1/6, çökme durumu anında ise 1 alınmaktadır.)

$T_{1}$ : Doğal titreşim periyodu

Doğal titreşim periyodu hesaplanırken yapıya önceden uygulanan sanal bir yükleme için katların ağırlık merkezlerinin yapacağı yer değiştirmeler hesaplanmaktadır. Bu hesaplanan yer değiştirmeler ve her bir katın kendi ağırlığı kullanılarak yönetmelikte verilen Eşitlik 10 formülü ile yapının doğal titreşim periyodu hesaplanmaktadir. 
$T_{1}=2 \pi \sqrt{\frac{\sum_{i=1}^{n}\left(W_{i} \cdot u_{i}^{2}\right)}{g \cdot \sum_{j=1}^{n}\left(F_{j} \cdot u_{j}\right)}}$

$T_{1}$ : Doğal titreşim periyodu

$W_{i}:$ Herhangi bir i. katın deprem hesabına esas ağırlığı

$u_{i}$ :Yapılan sanal yükleme sonucu elde edilen herhangi bir i. katın ağırlık merkezinin yaptığı deplasman

$F_{j}$ : Herhangi bir i. kata yüklenen sanal kuvvetin değeri

$g:$ Yer çekim ivmesi

$n$ :Yapıdaki toplam kat sayısı

Hesaplamalarda kullanılan $C_{b}$ katsayısı yönetmelikte Çizelge 5'teki gibi verilmiştir.

Çizelge 5. Hesaplanmış deprem ivmesi katsayıları (NZS 4203:1992)

Table 5. Calculated earthquake accelaration factors (NZS 4203:1992)

\begin{tabular}{|c|c|c|c|c|c|c|}
\hline \multirow{2}{*}{ PERIYOT (s) } & \multicolumn{7}{|c|}{ YAPISAL SÜNEKLİK KATSAYISI $(\boldsymbol{\mu})$} \\
\hline & 1,0 & 1,25 & 2,0 & 3,0 & 4,0 & 6,0 \\
\hline 0 & 0,40 & & & & & \\
\hline 0,10 & 0,80 & & & & & \\
\hline 0,15 & 1,00 & & & & & \\
\hline 0,20 & 1,00 & & & & & \\
\hline 0,25 & 0,96 & & & & & \\
\hline 0,30 & 0,89 & & & & & \\
\hline 0,35 & 0,84 & & & & & \\
\hline 0,40 & 0,80 & 0,69 & 0,47 & 0,38 & 0,28 & 0,20 \\
\hline 0,50 & 0,73 & 0,63 & 0,43 & 0,34 & 0,25 & 0,17 \\
\hline 0,60 & 0,67 & 0,58 & 0,39 & 0,31 & 0,22 & 0,14 \\
\hline 0,70 & 0,62 & 0,53 & 0,35 & 0,27 & 0,19 & 0,12 \\
\hline 0,80 & 0,57 & 0,49 & 0,32 & 0,25 & 0,17 & 0,107 \\
\hline 0,90 & 0,53 & 0,45 & 0,29 & 0,22 & 0,15 & 0,095 \\
\hline 1,00 & 0,50 & 0,42 & 0,26 & 0,20 & 0,13 & 0,087 \\
\hline 1,50 & 0,33 & 0,27 & 0,17 & 0,127 & 0,08 & 0,056 \\
\hline 2,00 & 0,25 & 0,20 & 0,13 & 0,097 & 0,06 & 0,042 \\
\hline
\end{tabular}

Yönetmelikte üç farklı zemin tipi belirlenmiştir. Zemin sınıfları birden fazla kriter ile birbirinden ayrılmaktadır. Zemin türleri Çizelge 6' da verilmiştir.

Çizelge 6. Zemin Sınıfları (NZS 4203:1992)

Table 6. Soil classes (NZS 4203:1992)

\begin{tabular}{|l|l|}
\hline ZEMİN TÜRÜ & \multicolumn{1}{|c|}{ AÇIKLAMA } \\
\hline a) Kaya ve çok sert zeminler & $-20 \mathrm{~m}^{\prime}$ den daha az drenajsız kesme dayanımı 100 $\mathrm{kPa}^{\prime} 1$ \\
& aşan kohezyonlu sert malzeme veya \\
& $-\mathrm{N}_{1}>30$ olan $20 \mathrm{~m}^{\prime}$ den az çok yoğun kum veya \\
& $-\mathrm{N}_{1}>30$ olan $25 \mathrm{~m}^{\prime}$ den az yoğun kumlu çakıl \\
\hline b) Orta zeminler & a veya c' ye dahil olmayan zeminler \\
\hline c) Esnek veya derin zeminler & - Doğal titreşim periyotları $0,6 \mathrm{~s}^{\prime}$ yi aşan zeminler \\
\hline
\end{tabular}

$\mathrm{N}_{1}: \mathrm{SPT}$ değeri 
Çizelge 7.Yapının risk durumu (NZS 4203: 1992) Table 7. Risc conditon of building (NZS 4203:1992)

\begin{tabular}{|c|l|c|}
\hline KATEGORI & \multicolumn{1}{|c|}{ YAPI TÜRÜ } & \multicolumn{1}{|c|}{ KATSAYI } \\
\hline I & $\begin{array}{l}\text { İnsan hayatını korumaya yönelik kullanılan ya da } \\
\text { fonksiyonunu kaybetmesinin toplumda büyük bir etki } \\
\text { yaratacağı binalar }\end{array}$ & 1,3 \\
\hline II & İnsanların toplu halde bulundukları binalar & 1,2 \\
\hline III & Toplumda büyük değere sahip olan kamu binaları & 1,1 \\
\hline IV & Diğger gruplara girmeyen binalar & 1,0 \\
\hline V & İkincil öneme sahip yapilar (ev v.b.) & 0,6 \\
\hline
\end{tabular}

Çizelge 8.Yapısal süneklik katsayısı (NZS 4203:1992)

\begin{tabular}{|c|l|c|}
\hline \multicolumn{3}{|c|}{ Table 8. Structural ductility factor (NZS 4203:1992). } \\
\hline SIRA NO & TAŞIYICI SİSTEM TÜR̈̈ & $\boldsymbol{\mu}$ \\
\hline 1 & Elastik yapılar & 1,25 \\
\hline \multirow{3}{*}{2} & Sünekliği sınırlandırılmış sistemler: & \\
& a) Güçlendirilmiş çerçeveler & - \\
& b) Eğilmeye çalışan çerçeveler & 3 \\
& c) Perdeli sistemler & 3 \\
\hline \multirow{3}{*}{3} & Sünek sistemler: & \\
& a) Güçlendirilmiş çerçeveler & - \\
& b) Eğilmeye çalışan çerçeveler & 6 \\
& c) Perdeli sistemler & 5 \\
\hline
\end{tabular}

Yunanistan Deprem Yönetmeliği (Greek Code For Seismic Resistant Structures - EAK2000)

Deprem hesabına esas yapı ağırlığı kullanılarak yapıya gelen deprem kuvveti hesaplanırken Eşitlik 11 formülü kullanılır.

$V_{0}=M \cdot \phi_{d}(T)$

$V_{0}$ :Toplam taban kesme kuvveti

$\mathrm{M}$ : Deprem hesabına esas yapı ağırlığ

$\phi_{d}(T)$ : Spektral ivme değeri (Şekil 2)

Çizelge 9. Zemin Sınıfları (EAK2000)

Table 9. Soil classes (EAK2000)

\begin{tabular}{|c|c|}
\hline $\begin{array}{l}\text { ZEMIN } \\
\text { SINIFI }\end{array}$ & AÇIKLAMA \\
\hline A & $\begin{array}{l}\text { - Geniş bir alan boyunca ve çok yüksek derinlikte uzanan çok kuru olmayan kaya } \\
\text { veya yarı kaya formatındaki zeminler. } \\
\text { - Çok küçük oranda kil - silt karışımı içeren } 70 \mathrm{~m}^{\prime} \text { den daha az kalınlığı olan } \\
\text { tabakalar. }\end{array}$ \\
\hline B & $\begin{array}{l}\text { - Mekanik özellikleri bakımından granüler madde olarak sayılabilen çok kuru kaya } \\
\text { ve zeminler } \\
\text { - Kalınlığı } 5 \text { m' den fazla orta yoğunluktaki granüler madde tabakaları veya yüksek } \\
\text { yoğunluktaki } 70 \text { m' den daha fazla kalınlığı olan granüler madde tabakaları }\end{array}$ \\
\hline$\Gamma$ & $\begin{array}{l}\text { - Kalınlığı } 5 \text { m' den fazla olan düşük göreceli yoğunluktaki granüler madde } \\
\text { tabakaları veya orta yoğunluktaki } 70 \text { m den fazla granüler madde tabakaları }\end{array}$ \\
\hline$\Delta$ & $\begin{array}{l}\text { - Toplam yüksekliği } 12 \text { m den fazla olan yüksek plastisite indeksine sahip }\left(l_{p}>60\right) \\
\text { yumuşak killer }\end{array}$ \\
\hline
\end{tabular}

$\mathrm{l}_{\mathrm{p}}$ :Plastisite indeksi 
Çizelge 10. Zemin sınıflarına bağlı olarak spektrum eğrisi sınır değerleri (EAK2000) Table 10. Spectrum graphic limit values according to the soil contions (EAK2000)

\begin{tabular}{|l|l|l|c|c|}
\hline ZEMIN SINIFI & A & B & $\boldsymbol{\Gamma}$ & $\boldsymbol{\Delta}$ \\
\hline $\mathrm{T}_{1}(\mathrm{~s})$ & 0,10 & 0,15 & 0,20 & 0,20 \\
\hline $\mathrm{T}_{2}(\mathrm{~s})$ & 0,40 & 0,60 & 0,80 & 1,20 \\
\hline
\end{tabular}

Yunanistan deprem yönetmeliğinde ülke deprem açısından 4 bölgeye ayrılmıştır. Deprem ivmesi ise Eşitlik 12' deki gibi hesaplanmaktadır:

$A=\alpha \cdot g$

A: Deprem ivmesi

$\alpha$ :Deprem bölge katsayısı (Çizelge 11)

$g$ :Yerçekimi ivmesi

Çizelge 11. Deprem bölge katsayıları (EAK2000)

Table 11. Seismic zone factors (EAK2000)

\begin{tabular}{|c|c|c|c|c|}
\hline Deprem Bölgeleri & I & II & III & IV \\
\hline $\boldsymbol{\alpha}$ & 0,12 & 0,16 & 0,24 & 0,36 \\
\hline
\end{tabular}

Çizelge 12.Bina önem katsayısı (EAK2000)

Table 12. Building importance factor (EAK2000)

\begin{tabular}{|c|c|c|}
\hline KATEGORİ & \multicolumn{1}{|c|}{ YAPI TÜRÜ } & $\begin{array}{c}\text { KATSAYI } \\
\left(\gamma_{I}\right)\end{array}$ \\
\hline$\Sigma 1$ & $\begin{array}{l}\text { Halk güvenliği açısından çok az öneme sahip binalar } \\
\text { (tarımsal yapılar, ahır, hangar, baraka, kulübe v.b.) }\end{array}$ & 0,85 \\
\hline$\Sigma 2$ & $\begin{array}{l}\text { Normal mesken binaları, ofis binaları, endüstriyel } \\
\text { binalar, oteller }\end{array}$ & 1,0 \\
\hline$\Sigma 3$ & $\begin{array}{l}\text { Okul binaları, meclis binaları, havaalanları, insanların } \\
\text { büyük bir çoğunluğunun günün önemli bir bölümünü } \\
\text { geçirdiği binalar, yapım maliyetleri çok yüksek olan } \\
\text { binalar (özel endüstriyel binalar v.b.) }\end{array}$ & 1,15 \\
\hline$\Sigma 4$ & $\begin{array}{l}\text { Deprem sırasında veya depremden hemen sonra } \\
\text { kullanılması hayati önem taşyan binalar } \\
\text { (telekomünikasyon binaları, enerji binaları, hastaneler, } \\
\text { yangın istasyonları v.b.), sanatsal olarak çok önemli olan } \\
\text { anitsal binalar (müzeler v.b.) }\end{array}$ & 1,30 \\
\hline
\end{tabular}

Çizelge 13.Davranış katsayısı (EAK2000)

Table 13. Structural behaviour factors (EAK2000)

\begin{tabular}{|l|l|l|}
\hline MALZEME & \multicolumn{1}{|c|}{ TAŞIYICI SİSTEM TÜRÜ } & q \\
\hline \multirow{5}{*}{ BETONARME } & Çerçeveler ve karma sistemler & 3,50 \\
\cline { 2 - 3 } & Konsol çalışan duvarları olan yapılar & 3,00 \\
\cline { 2 - 3 } & $\begin{array}{l}\text { Toplam yapı ağırlığının en az \%50' sinin toplam } \\
\text { bina yüksekliğinin 1/3' ünden yukarısında olan } \\
\text { binalar }\end{array}$ & 2,00 \\
\hline
\end{tabular}


Çizelge 14. Temel katsayısı (EAK2000)

Table 14. Foundation factors (EAK2000)

\begin{tabular}{|l|c|}
\hline TEMEL TÜRÜ & $\boldsymbol{\theta}$ \\
\hline Bir tane temeli olan binalar & 0,90 \\
\hline Radye temelli binalar & 0,90 \\
\hline Kazık başlı̆̆ı kirişlerine oturan kazık temelli binalar & 0,90 \\
\hline En az iki temeli olan binalar & 0,80 \\
\hline En az bir temeli ve bir radye temeli olan binalar & 0,80 \\
\hline Yaygın bir kazık başlı̆̆ı ile bağlı kazınlar üzerine oturan binalar & 0,80 \\
\hline
\end{tabular}

Çizelge 15. Sönüm oranları (EAK2000)

Table 15. Damping values (EAK2000)

\begin{tabular}{|c|c|c|}
\hline \multicolumn{2}{|r|}{ Yapı Türü } & Sönüm Oranı $(\zeta)(\%)$ \\
\hline \multirow{2}{*}{ Çelik } & Kaynaklı birleşim & 2 \\
\hline & Bulonlu birleşim & 4 \\
\hline \multirow{3}{*}{ Beton } & Beton & 3 \\
\hline & Betonarme & 5 \\
\hline & Ön germeli & 4 \\
\hline \multirow{2}{*}{ Yığma } & Betonarme & 6 \\
\hline & Sınırlandırılmış & 5 \\
\hline \multirow{3}{*}{ Ahşap } & Tutkallı birleşim & 4 \\
\hline & Bulonlu birleşim & 4 \\
\hline & Çivili birleşim & 5 \\
\hline
\end{tabular}

Yukarıdaki çizelgelerden alınan değerler kullanılarak ve yapının spektrum eğrisi dikkate alınarak yapıya gelecek deprem kuvvetini hesaplamada kullanılacak bir katsayı hesap edilir. Bu katsayının hesabında kullanılacak spektrum eğrisi Şekil 2' de verilmiştir. Zemin sınıfına göre spektrum eğrisini sınırlayan değerler Çizelge 10' da verilmiştir. Bu değerler yardımı ile katsayının nasıl hesaplanacağı Eşitlik 13, 14 ve 15 ile birlikte verilmiştir.

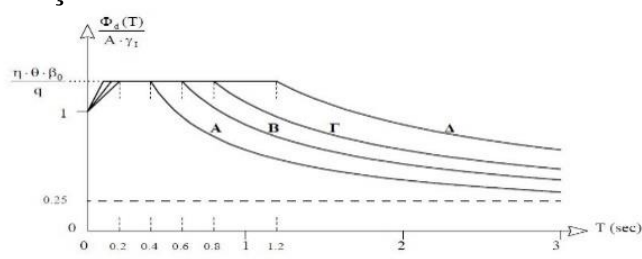

Şekil 2. Spektrum eğrisi (EAK2000)

Figure 2. Spectrum graphic (EAK2000)

$0 \leq T<T_{1} \phi_{d}(T)=\gamma_{I} \cdot A\left[1+\frac{T}{T_{1}} \cdot\left(\frac{\eta \cdot \theta \cdot \beta_{0}}{q}-1\right)\right]$

$T_{1} \leq T \leq T_{2} \phi_{d}(T)=\gamma_{I} \cdot A \cdot \frac{\eta \cdot \theta \cdot \beta_{0}}{q}$

$T_{2}<T \phi_{d}(T)=\gamma_{I} \cdot A \cdot \frac{\eta \cdot \theta \cdot \beta_{0}}{q} \cdot\left(T_{2} / T\right)^{2 / 3}$

$\phi_{d}(T)$ :Spektral ivme değeri

$\gamma_{I}$ :Yapı önem katsayısı (Çizelge 12)

$A$ :Deprem ivmesi

$T$ :Doğal titreşim periyodu

$T_{1}$ :Zemin sınıfına bağlı karakteristik periyot değeri

$T_{2}$ :Zemin sınıfına bağlı karakteristik periyot değeri

$\eta$ :Sönüm düzenleme katsayısı

$\theta$ :Temel katsayısı (Çizelge 14)

$\beta_{0}$ :Spektral büyütme katsayısı (2,50 alınabilir.)

$q$ :Yapı davranış katsayısı (Çizelge 13) 
$\zeta$ :Sönüm oranı (Çizelge 15)

$\eta=\sqrt{\frac{7}{2+\zeta}} \geq 0,7$

(16)

Sönüm düzenleme katsayısı Eşitlik 16 formülü ile hesaplanır.

$\frac{\phi_{d}(T)}{A \cdot \gamma_{I}} \geq 0,25$

Eşitlik 17 formülü her durum için sağlanmalıdır.

Yönetmelikte doğal titreşim periyodunun hesaplanabilmesi için yaklaşık bir yöntem olan Eşitlik 18 formülü verilmiştir. Ancak literatürde kabul görmüş farklı yöntemlerin kullanılmasına da müsaade etmektedir.

$T=0,09 \cdot \frac{H}{\sqrt{L}} \cdot \sqrt{\frac{H}{H+\rho \cdot L}}$

$T$ : Doğal titreşim periyodu

$H$ :Toplam bina yüksekliği

$L$ :Hesap yapılacak yönde binanin plandaki uzunluğu

$\rho$ : Hesap yönündeki toplam duvar kesit alanının hesap yönündeki toplam kolon ve duvar kesit alanına oranı

İran Deprem Yönetmeliği (Iranian Code Of Practice For Seismic Resistant Design Of Buildings - Standard 2800)

Yapıya etki edecek yatay yük Eşitlik 19 formülü ile hesaplanır.

$\mathrm{V}=C \cdot W$

$\mathrm{V}$ :Toplam taban kesme kuvveti

$W$ : Deprem hesabına esas yapı ağırlı̆̆ı

C: Deprem katsayısı

Yönetmelikte spektrum katsayısının doğal titreşim periyoduna bağlı olarak nasıl hesaplanacağı aşağıda tanımlanmıştır. Ayrıca Şekil 3’ te zemin türlerine bağlı olarak spektrum eğrisi verilmiştir:

$0 \leq T \leq T_{0} \mathrm{~B}=1+\mathrm{S}\left(\frac{T}{T_{0}}\right)$

$T_{0} \leq T \leq T_{S} \mathrm{~B}=1+\mathrm{S}$

$T_{s} \leq T \mathrm{~B}=(1+\mathrm{S})\left(T_{s} / T\right)^{2 / 3}$

$B$ :Spektrum katsayısı

$T$ :Doğal titreşim periyodu

$T_{0}$ :Zemin sınıfına bağlı karakteristik periyot değeri

$T_{s}$ :Zemin sınıfına bağlı karakteristik periyot değeri

$S$ :Spektrum katsayısının hesaplanmasında kullanılan bir katsayı

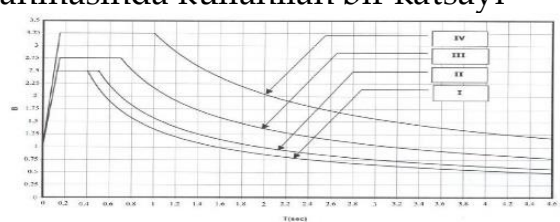

Şekil 3. Spektrum eğrisi (Standard 2800)

Figure 3. Spectrum graphic (Standard 2800)

Doğal titreşim periyodu hesaplanırken öncelikle yapıya etki edecek rastgele seçilmiş bir deprem kuvveti katlara yönetmelikte belirtildiği gibi dağıtılır. Seçilen deprem kuvveti etkisi altındaki kat yer değiştirmeleri hesaplanır ve Eşitlik 23 yardımı ile doğal titreşim periyodu hesaplanır. 
$\mathrm{T}=2 \pi \sqrt{\frac{\sum_{i=1}^{n}\left(W_{i} \cdot \delta_{i}^{2}\right)}{g \cdot \sum_{i=1}^{n}\left(F_{i} \cdot \delta_{i}\right)}}$

$T$ : Doğal titreşim periyodu

$W_{i}:$ Herhangi bir i. katın depreme esas ağırlığı

$\delta_{i}$ :Herhangi bir i. katın verilen deprem kuvveti etkisinde yaptığ

$F_{i}$ : Herhangi bir i. kata uygulanan deprem kuvveti

$n$ :Toplam kat sayısı

$g$ :Yerçekim ivmesi

Yapıya etki edecek deprem kuvveti depreme esas yapı ağırlı̆̆ının bir katsayı ile çarpılması sonucu bulunmaktadır. Bu katsayı Eşitlik 24 ile hesaplanmaktadır:

$C=\frac{A \cdot B \cdot I}{R}$

C:Deprem katsayısı

A:Deprem ivme katsayısı (Çizelge 17)

B:Spektrum katsayısı (Şekil 4)

I:Yapı önem katsayısı (Çizelge 19)

R:Yapı davranış katsayısı (Çizelge 20)

Deprem yönetmeliğinde toplamda 4 farklı zemin türü tanımlanmıştır. Bu zeminler Çizelge 16' da verilmiştir.

Çizelge 16. Zemin Sınıfları (Standard 2800)

Table 16. Soil Classes (Standard 2800)

\begin{tabular}{|c|c|c|}
\hline ZEMIN SINIFI & AÇIKLAMA & $\bar{V}_{s}(m / s)$ \\
\hline $\mathrm{I}$ & $\begin{array}{l}\text { - Volkanik kayaçlar, rijitsedimenter kayaçlar } \\
\text { ve metamorfik kayaçlar } \\
\text { - } 30 \text { metreden daha fazla kalınlığı olan rijit } \\
\text { zeminler (sıkı kum ve çakıl, çok rijit kil) }\end{array}$ & $375 \leq \bar{V}_{s} \leq 750$ \\
\hline II & $\begin{array}{l}\text { - Gevşek volkanik kayaçlar, gevşek sedimenter } \\
\text { kayaçlar } \\
\text { - } 30 \text { metreden daha fazla kalınlığı olan rijit } \\
\text { zeminler (sıkı kum ve çakıl, çok rijit kil) }\end{array}$ & $\begin{array}{l}375 \leq \bar{V}_{s} \leq 750 \\
375 \leq \bar{V}_{s} \leq 750\end{array}$ \\
\hline III & $\begin{array}{l}\text { - Nemden dolayı parçalanan kayalar } \\
\text { - Orta seviyede kompaksiyon yapılmış } \\
\text { zeminler, taneler arası bağları orta seviye olan } \\
\text { kum ve çakıl tabakaları ve orta seviyede } \\
\text { kompaksiyon yapılmış killer }\end{array}$ & $\begin{array}{l}175 \leq \bar{V}_{s} \leq 375 \\
175 \leq \bar{V}_{s} \leq 375\end{array}$ \\
\hline IV & $\begin{array}{l}\text { - Yüksek seviyede su tabaksı nedeniyle aşırı } \\
\text { nem içeren yumuşak zeminler }\end{array}$ & $<175$ \\
\hline
\end{tabular}

$\bar{V}_{s}(m / s)$ :Ortalama kayma dalgası hızı

Çizelge 17. Deprem ivme katsayısı (Standard 2800)

Table 17. Seismic acceleration coefficients (Standard 2800)

\begin{tabular}{|c|l|c|}
\hline Bölge & \multicolumn{1}{|c|}{ Açıklama } & İvme (/g) \\
\hline 1 & Aşırı yüksek depremsellik & 0,35 \\
\hline 2 & Yüksek depremsellik & 0,30 \\
\hline 3 & Orta depremsellik & 0,25 \\
\hline 4 & Düşük depremsellik & 0,20 \\
\hline
\end{tabular}


Çizelge 18. Zemin sınıfına ve deprem bölgesine bağlı olarak spektrum eğrisi sınır değerleri (Standard 2800)

Table 18. Spectrum curve limit values with respect to the soil class and eartquake zones (Standard 2800)

\begin{tabular}{|c|c|c|c|c|}
\hline \multirow[t]{2}{*}{$\begin{array}{l}\text { ZEMİN } \\
\text { SINIFI }\end{array}$} & \multirow[t]{2}{*}{$T_{0}$} & \multirow[t]{2}{*}{$T_{s}$} & $\begin{array}{l}\text { ORTA VE DÜŞÜK } \\
\text { SEVIYEDE } \\
\text { DEPREMSELLIIK }\end{array}$ & $\begin{array}{c}\text { YÜKSEK VE AŞIRI YÜKSEK } \\
\text { SEVIYEDE } \\
\text { DEPREMSELLIK }\end{array}$ \\
\hline & & & $\mathrm{S}$ & $\mathrm{S}$ \\
\hline I & 0,10 & 0,40 & 1,50 & 1,50 \\
\hline II & 0,10 & 0,50 & 1,50 & 1,50 \\
\hline III & 0,15 & 0,70 & 1,75 & 1,75 \\
\hline IV & 0,15 & 1,00 & 2,25 & 1,75 \\
\hline
\end{tabular}

Çizelge 19. Bina önem katsayısı (Standard 2800) Table 19. Building importance factors (Standard 2800)

\begin{tabular}{|c|c|}
\hline KATEGORİ & KATSAYI (I) \\
\hline Grup 1 & 1,40 \\
\hline Grup 2 & 1,20 \\
\hline Grup 3 & 1,00 \\
\hline Grup 4 & 0,80 \\
\hline
\end{tabular}

Çizelge 20. Davranış katsayısı (Standard 2800)

Table 20. Structural response values (Standard 2800)

\begin{tabular}{|c|c|c|c|}
\hline TAŞIYICI SISTEM & YATAY KUVVETİ TAŞIYAN SİSTEM & $\mathbf{R}$ & $H_{m}(M)$ \\
\hline \multirow{4}{*}{$\begin{array}{l}\text { Perdeli } \\
\text { Sistemler }\end{array}$} & Özel betonarme perdeli sistemler & 8 & 50 \\
\hline & Orta betonarme perdeli sistem & 7 & 50 \\
\hline & Normal betonarme perdeli sistem & 5 & 30 \\
\hline & Betonarme yığma & 4 & 15 \\
\hline \multirow{3}{*}{$\begin{array}{l}\text { Moment } \\
\text { Taşıyan } \\
\text { Çerçeve } \\
\text { Sistem }\end{array}$} & Özel betonarme çerçeve sistem & 10 & 150 \\
\hline & Orta betonarme çerçeve sistem & 7 & 50 \\
\hline & Normal betonarme çerçeve sistem & 4 & -- \\
\hline \multirow{2}{*}{$\begin{array}{c}\text { Karma } \\
\text { Sistemler }\end{array}$} & Özel betonarme çerçeve + özel betonarme perdeli sistem & 11 & 200 \\
\hline & Orta betonarme çerçeve + orta betonarme perdeli sistem & 8 & 70 \\
\hline
\end{tabular}

Avrupa Birliği Deprem Yönetmeliği (Eurocode - 8) (Europe unity earthquake code (Eurocode - 8))

Toplam taban kesme kuvveti hesaplanması Eşitlik 25 ile yapılmaktadır.

$F_{b}=S_{d}(T) \cdot m \cdot \lambda$

$F_{b}$ :Toplam taban kesme kuvveti

$S_{d}(T)$ : Tasarım spektrum katsayısı

$\lambda: T \leq 2 T_{C}$ olduğu durumda $\lambda=0,85$ alınabilir ya da yapı iki katlıdan daha fazla ise $\lambda=1,0$ alınabilir.

Yönetmelikte tanımlanan iki farklı spektrum eğrisi bulunmaktadır. Tip 1 ve tip 2 olarak adlandırılan bu eğrilerden tip 1 deprem yüzey dalgasının magnitüd büyüklüğü $\left(M_{s}>5,5\right)$ 5,5' den büyük ise geçerlidir. Küçük olması durumunda tip 2 geçerli olur. Eğriler \%5 sönüm oranı dikkate alınarak hazırlanmış eğrilerdir. Bu eğriler elastik durum için geçerli eğrilerdir. Tasarım sırasında kullanılacak spektrum için denklemler aşağıda verilmiştir. Tip 1 için spektrum eğrisi sınır değerleri Çizelge $21^{\prime}$ de verilmiştir. Genel spektrum eğrisi Şekil 4' te Tip 1 spektrum eğrisi ise Şekil 5' de tanımlanmıştır. 


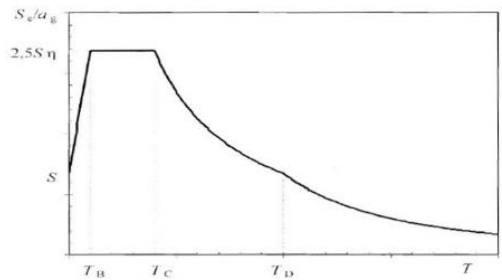

Şekil 4. Genel spektrum eğrisi (Eurocode -8)

Figure 4. General spectrum graphic (Eurocode-8)

$0 \leq T \leq T_{B} S_{d}(T)=a_{g} \cdot S \cdot\left(\frac{2}{3}+\frac{T}{T_{B}} \cdot\left(\frac{2,5}{q}-\frac{2}{3}\right)\right)$

$T_{B} \leq T \leq T_{C} S_{d}(T)=a_{g} \cdot S \cdot \frac{2,5}{q}$

$T_{C} \leq T \leq T_{D} S_{d}(T)=a_{g} \cdot S \cdot \frac{T_{C}}{T} \cdot \frac{2,5}{q}$

$T_{D} \leq T S_{d}(T)=a_{g} \cdot S \cdot\left(\frac{T_{c} \cdot T_{D}}{T^{2}}\right) \cdot \frac{2,5}{q}$

$S_{d}(T)$ :Tasarım spektrum katsayısı

$T$ :Doğal titreşim periyodu

$T_{B}$ :Zemin sınıfına bağlı karakteristik periyot değeri (Çizelge 22)

$T_{C}$ :Zemin sınıfına bağlı karakteristik periyot değeri (Çizelge 22)

$T_{D}$ :Zemin sınıfına bağlı karakteristik periyot değeri (Çizelge 22)

$S$ :Zemin faktörü (Çizelge 22)

$q$ :Yapı davranış katsayısı (Çizelge 24)

$a_{g}$ : Deprem hareketi katsayısı

$\gamma_{1}$ : Yapı önem katsayısı (Çizelge 23)

$a_{g R}$ :Deprem bölge katsayısıdır. Bu katsayı her ülkenin kendi yönetmeliklerinden alınmaktadır. Ancak her ne olursa olsun $a_{g}=0,08 \mathrm{~g}\left(0,78 \mathrm{~m} / \mathrm{s}^{2}\right)$ değerini geçemez.

$a_{g}=\gamma_{1} \cdot a_{g R}$

$a_{g}$ Eşitilk 30 formülü ile hesaplanır.

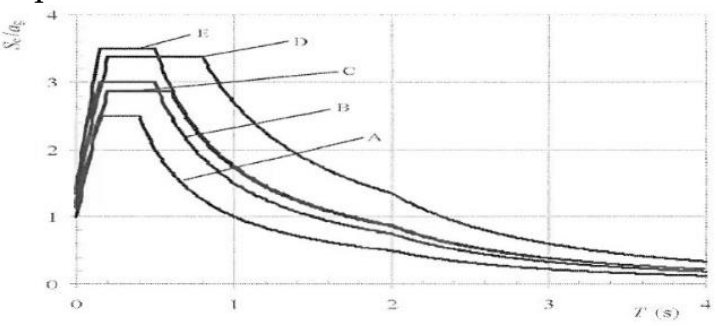

Şekil 5. Tip 1 için elastik spektrum eğrisi (Eurocode - 8)

Figure 5. Spectrum graphic for type 1 (Eurocode -8)

Çizelge 21. Spektrum eğrisi sınır değerleri (Eurocode - 8)

Table 21. Spectrum graphic limit values (Eurocode -8)

\begin{tabular}{|c|c|c|c|c|}
\hline ZEMİN TÜRÜ & $\mathbf{S}$ & $\mathbf{T}_{\mathbf{B}} \mathbf{( s )}$ & $\mathbf{T}_{\mathbf{C}} \mathbf{( s )}$ & $\mathbf{T}_{\mathbf{D}} \mathbf{( s )}$ \\
\hline $\mathrm{A}$ & 1,0 & 0,15 & 0,40 & 2,00 \\
\hline $\mathrm{B}$ & 1,2 & 0,15 & 0,50 & 2,00 \\
\hline $\mathrm{C}$ & 1,15 & 0,20 & 0,60 & 2,00 \\
\hline $\mathrm{D}$ & 1,35 & 0,20 & 0,80 & 2,00 \\
\hline $\mathrm{E}$ & 1,4 & 0,15 & 0,50 & 2,00 \\
\hline
\end{tabular}

Doğal titreşim periyodunun hesaplanabilmesi için yönetmelikte (31) ve (32) olmak üzere iki farklı metot sunulmuştur. Bu metotlar spektrum katsayısını elde edebilmek için ilk etapta kullanılması gereken yaklaşık periyot hesabı için kullanılması gereken formüllerdir. 
$T=C_{t} \cdot H^{3 / 4}$

$C_{t}=0,0075 / \sqrt{A_{C}}$

$A_{C}=\sum\left(A_{i} \cdot\left(0,2+\left(l_{w i} / H\right)^{2}\right)\right)$

$T$ : Doğal titreşim periyodu

$C_{t}$ :Betonarme uzay çerçeve sistemlerde 0,075 alınır. Ĕger yapıda perde varsa veya yı̆̆ma ise Eşitlik 33 formülü ile hesap yapilır.

$\mathrm{H}:$ Bina toplam yüksekliği

$A_{c}$ : İlk kattaki toplam etkili perde alanı $\left(\mathrm{m}^{2}\right)$

$A_{i}$ : İlk kattaki hesap doğrultusundaki toplam etkili perde kesit alanı $\left(\mathrm{m}^{2}\right)$

$l_{w i}$ : İlk kattaki deprem kuvveti uygulama doğrultusuna paralel toplam perde uzunluğu $\left(l_{w i} / H \leq 0,9\right.$ olmali)

$T=2 \cdot \sqrt{d}$

$T$ : Doğal titreşim periyodu

$d$ : Yapıya etki eden düşey yüklerin yatay olarak yapıya etki ettirilmesi sonucu en üst katta elde edilen deplasman

Yönetmelikte 5 farklı zemin tipi tanımlanmıştır. Ayrıca özel olarak iki farklı zemin türü daha tanımlanmıştır. Bu zeminler için belirli kriterler Çizelge 22' de verilmiştir.

Çizelge 22. Zemin Sinıfları (Eurocode - 8)

Table 22. Soil classes (Eurocode -8 )

\begin{tabular}{|c|c|c|c|c|}
\hline $\begin{array}{l}\text { ZEMIN } \\
\text { SINIFI }\end{array}$ & AÇIKLAMA & $v_{s, 30}(m / s)$ & $N_{S P T}$ & $c_{u}(k P a)$ \\
\hline A & $\begin{array}{l}\text { Kaya ve jeolojik açıdan kaya benzeri formatta } \\
\text { olan zeminler (en fazla } 5 \text { metre zayıf malzeme } \\
\text { içeren) }\end{array}$ & $>800$ & - & - \\
\hline B & $\begin{array}{l}\text { Mekanik özellikleri derinlikle artan en az } 10 \text { m } \\
\text { kalınlığında çok yoğun sıkı kum, çakıl veya } \\
\text { çok rijit kil zeminler }\end{array}$ & $360-800$ & $>50$ & $>250$ \\
\hline C & $\begin{array}{l}\text { Kalınlığ } 50 \mathrm{~m}^{\prime} \text { den } 100 \mathrm{~m}^{\prime} \text { lere kadar olan sık1 } \\
\text { yoğun veya orta yoğun kum, çakıl veya rijit kil } \\
\text { zeminler }\end{array}$ & $180-360$ & $15-50$ & $70-250$ \\
\hline $\mathrm{D}$ & S1kı nemli kohezyonsuz zeminler & $<180$ & $<15$ & $<70$ \\
\hline $\mathrm{E}$ & $\begin{array}{l}\text { Kalınlığ } 5 \mathrm{~m} \text { ve } 20 \mathrm{~m} \text { arasında olan, } v_{s} \text { değeri } \mathrm{C} \\
\text { ve } \mathrm{D} \text { tipteki kadar olan yüzeyinde alüvyal } \\
\text { tabaka bulunan altındaki rijit tabakada } v_{s}>800 \\
\text { olan bir zemin profili }\end{array}$ & & & \\
\hline $\mathrm{S}_{1}$ & $\begin{array}{l}\text { En az } 10 \mathrm{~m} \text { kalınlığında yüksek plastisite } \\
\text { indeksine sahip }(\mathrm{PI}>40) \text { yumuşak kil/silt içeren } \\
\text { zeminler }\end{array}$ & $<100$ & - & $10-20$ \\
\hline $\mathrm{S}_{2}$ & $\begin{array}{l}\text { Sıvılaştırılabilen hassas kil tabakaları veya } \\
\text { başka bir gruba dâhil olmayan diğer zemin } \\
\text { türleri }\end{array}$ & & & \\
\hline
\end{tabular}

$v_{s, 30}(m / s)$ :Ortalama kayma dalgası hızıPI:Plastisite indeksi 
Çizelge 23. Yapı önem katsayısı (Eurocode - 8) Table 23. Building importane factor (Eurocode -8)

\begin{tabular}{|c|l|c|}
\hline YAPI ÖNEM SINIFI & \multicolumn{1}{|c|}{ YAPI TÜRLERI } & $\boldsymbol{\gamma}_{\mathbf{1}}$ \\
\hline I & $\begin{array}{l}\text { Halk güvenliği açısından çok önemli olmayan binalar } \\
\text { (tarımsal yapılar) }\end{array}$ & 0,8 \\
\hline II & $\begin{array}{l}\text { Normal yapılar, diğer gruplara dahil olmayan yapı } \\
\text { türleri }\end{array}$ & 1,0 \\
\hline III & $\begin{array}{l}\text { Deprem dayanımı büyük önem taşıyan yıkılması } \\
\text { istenmeyen yapılar (okullar, toplantı ve meclis binaları, } \\
\text { kültürel kuruluşlar) }\end{array}$ & 1,2 \\
\hline IV & $\begin{array}{l}\text { Deprem sirasinda yapının bütünlüğünün korunabilmesi } \\
\text { halkın korunması açısından büyük önem taşıyan binalar } \\
\text { (hastaneler, yangın istasyonları, enerji merkezleri) }\end{array}$ & 1,4 \\
\hline
\end{tabular}

Çizelge 24. Yapı davranış katsayısı (Eurocode - 8) Table 24. Building behaviour factors (Eurocode -8)

\begin{tabular}{|l|c|}
\hline \multicolumn{1}{|c|}{ YAPI TÜRÜ } & DAVRANIŞ KATSAYISI (q) \\
\hline Çerçeve Sistem & $3,0 \alpha_{0} / \alpha_{1}$ \\
\hline Kirişsiz perde sistem & 3,0 \\
\hline Burulma rijitliği olmayan sistemler & 2,0 \\
\hline $\begin{array}{l}\text { Ağırlığının \%50' den fazlası yapının 3' de } 1^{\prime} \\
\text { inden yukarıda olan sistemler }\end{array}$ & 1,5 \\
\hline
\end{tabular}

$\alpha_{0} / \alpha_{1}$ değeri kat sayısına ve açıklık miktarına göre değişik değerler almaktadır.

Tek katlı yapılar için $\alpha_{0} / \alpha_{1}=1,1$

Çok katlı tek açıklıklı yapılar için $\alpha_{0} / \alpha_{1}=1,2$

Çok katlı çok açıklıklı yapılar için $\alpha_{0} / \alpha_{1}=1,3$ olarak alınabilir.

Türk Deprem Yönetmeliği (TBDY - 2018) (Turkish Earthquake Code (TBDY - 2018))

Yapıya etki edecek eşdeğer deprem yükü azaltılmış tasarım spektral ivmesi ile yapının deprem hesabına esas ağırlığının çarpılması ile bulunur (Eşitlik 35).

$$
\mathrm{V}_{t E}^{(x)}=m_{t} S_{a R}\left(T_{p}^{(x)}\right) \geq 0,04 m_{t} I S_{D S} g
$$

$\mathrm{V}_{t E}^{(x)}$ : Göz önüne alınan deprem doğrultusundaki toplam taban kesme kuvveti

$m_{t}$ : Deprem hesabına esas yapı ağırlı̆̆1

$S_{a R}\left(T_{p}^{(x)}\right)$ :Binanın hâkim doğal titreşim periyoduna göre hesaplanan azaltılmış tasarım spektral ivme katsayısı

$S_{D S}:$ Tasarım spektral ivme katsayısı

$I$ :Bina önem katsayısı

$g$ : Yer çekimi ivmesi

Eşdeğer deprem yükü metodunun kullanılabilmesi için doğal titreşim periyodunun bulunması gerekmektedir. Yönetmeliğimiz doğal titreşim periyodunun hesaplanacağı bir formül tanımlamıştır. Bu formül kullanılırken yapıya etki edecek sanal bir deprem yükü belirlenmelidir. Bu fiktif yük katlara dağıtılarak yapının yer değiştirmeleri elde edilir ve Eşitlik 36'daki formülde yerine koyularak doğal titreşim periyodu hesaplanur.

$$
\begin{aligned}
& T_{p}^{(x)}=2 \pi\left(\frac{\sum_{i=1}^{N} m_{i} d_{f i}^{(x) 2}}{\sum_{i=1}^{N} F_{f i}^{(x)} d_{f i}^{(x)}}\right)^{1 / 2} \\
& T_{p}^{(x)}: \text { Binanın hâkim doğal titreşim periyodu }
\end{aligned}
$$


$m_{i}$ :Herhangi bir i. katın depreme esas ağırlığı

$d_{f i}^{x}:$ Herhangi bir i. katın verilen deprem kuvveti(fiktif yük) etkisinde yaptığı yer değiştirme

$F_{f i}$ : Herhangi bir i. kata uygulanan deprem kuvveti (fiktif yük)

$N$ :Toplam kat sayısı

Yönetmeliğimizde tanımlanan spektrum eğrisi yardımı ile yapının doğal titreşim periyoduna bağlı olarak spektrum katsayısı belirlenmektedir. Yönetmeliğimizde tanımlanan spektrum eğrisi Şekil $6^{\prime}$ da verilmiştir.

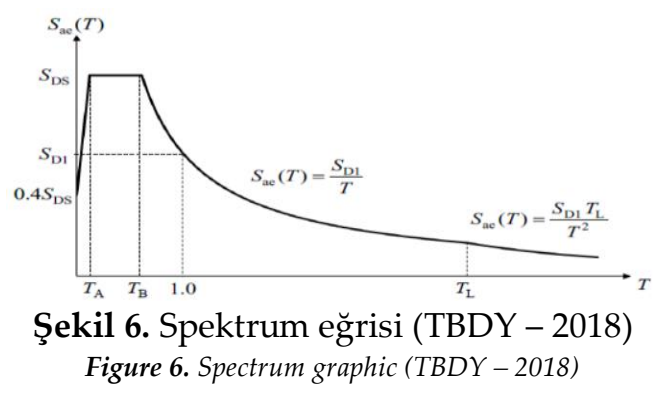

Eğride bulunan bölgelere göre spektrum katsayıları Eşitilk 37, 38, 39 ve 40 eşitlikleri yardımıyla hesaplanabilmektedir

$$
\begin{aligned}
& 0 \leq T \leq T_{A} \quad \mathrm{~S}_{a e}(\mathrm{~T})=\left(0,4+0,6 \frac{T}{T_{A}}\right) S_{D S} \\
& T_{A} \leq T \leq T_{B} \quad \mathrm{~S}_{a e}(\mathrm{~T})=S_{D S} \\
& T_{B} \leq T \leq T_{L} \quad \mathrm{~S}_{a e}(\mathrm{~T})=\frac{S_{D l}}{T} \\
& T_{L} \leq T \quad \mathrm{~S}_{a e}(\mathrm{~T})=\frac{S_{D l} T_{L}}{T^{2}}
\end{aligned}
$$

$\mathrm{S}_{a e}(\mathrm{~T})$ : Elastik tasarım spektral ivmesi

$T$ :Doğal titreşim periyodu

$S_{D S}$ : Tasarım spektral ivme katsayısı

$S_{D l}$ : Tasarım spektral ivme katsayısı

$T_{A}$ :Yatay tasarım spektrumu köşe periyodu

$T_{B}$ : Yatay tasarım spektrumu köşe periyodu

$T_{L}$ : Sabit yerdeğiştirme bölgesine geçiş periyodu (6 s olarak alınabilir.)

Yatay tasarım spektrumu köşe periyodu olan $T_{A}$ ve $T_{B}$ Eşitlik 41 ve 42 formülleri ile hesaplanmaktadir.

$$
\begin{aligned}
& T_{A}=0,2 \frac{S_{D l}}{S_{D S}} \\
& T_{B}=\frac{S_{D l}}{S_{D S}}
\end{aligned}
$$

Tasarım spektral ivme katsayıları olan $S_{D S}$ ve $S_{D l}$ TBDY-2018 de tanımlanan denklemler ile hesaplanmaktadır. Aşağıdaki Eşitilk 43 ve 44 formülleri ile hesaplanabilmektedir.

$$
\begin{aligned}
& S_{D S}=S_{S} F_{S} \\
& S_{D l}=S_{l} \gamma_{F} F_{l}
\end{aligned}
$$

Burada, $S_{S}$ kısa periyod bölgesi için harita spektral ivme katsayısını, $S_{l} 1,0$ saniye periyod için harita spektral ivme katsayısını, $F_{S}$ ve $F_{l}$ yerel zemin etki katsayılarını, $\gamma_{F}$ faya yakınlık katsayısını ifade etmektedir.

Faya yakınlık katsayısı aşağıdaki gibi hesaplanmaktadır.

$$
\begin{array}{ll}
L_{F} \leq 15 \mathrm{~km} & \gamma_{F}=1,2 \\
15 \mathrm{~km} \leq L_{F} \leq 25 \mathrm{~km} & \gamma_{F}=1,2-0,02\left(L_{F}-15\right)
\end{array}
$$

$S_{S}$ ve $S_{l}$ katsayıları www.deprem.gov.tr adresinde verilen Deprem Tehlike Haritalarında harita spektral ivmelerinin yerçekimi ivmesine bölünmesiyle boyutsuz olarak elde edilir.

$F_{S}$ ve $F_{l}$ yerel zemin etki katsayıları Çizelge 25 ve Çizelge $26^{\prime}$ da verilmiştir. Ara değerler için doğrusal enterpolasyon yapılabilmektedir. 
Çizelge 25. Kısa periyot bölgesi için Yerel Zemin Etki Katsayıları (TBDY-2018) Table 25. Local soil impact factor for short period (TBDY-2018)

\begin{tabular}{|c|c|c|c|c|c|c|}
\hline \multirow{2}{*}{$\begin{array}{c}\text { YEREL ZEMIN } \\
\text { SINIFI }\end{array}$} & \multicolumn{7}{|c|}{ Kisa periyot bölgesi için Yerel Zemin Etki Katsayı1 $\boldsymbol{F}_{\boldsymbol{S}}$} \\
\cline { 2 - 7 } & $S_{S} \leq 0,25$ & $S_{S}=0,50$ & $S_{S}=0,75$ & $S_{S}=1,00$ & $S_{S}=1,25$ & $S_{S} \geq 1,50$ \\
\hline ZA & 0,8 & 0,8 & 0,8 & 0,8 & 0,8 & 0,8 \\
\hline ZB & 0,9 & 0,9 & 0,9 & 0,9 & 0,9 & 0,9 \\
\hline ZC & 1,3 & 1,3 & 1,2 & 1,2 & 1,2 & 1,2 \\
\hline ZD & 1,6 & 1,4 & 1,2 & 1,1 & 1,0 & 1,0 \\
\hline ZE & 2,4 & 1,7 & 1,3 & 1,1 & 0,9 & 0,8 \\
\hline ZF & \multicolumn{7}{|c|}{ Sahaya özel zemin davranış analizi yapilacaktır. } \\
\hline
\end{tabular}

Çizelge 26. 1,0 saniye periyot için Yerel Zemin Etki Katsayıları (TBDY-2018) Table 26. Local soil impact factor for 1,0 second period (TBDY-2018)

\begin{tabular}{|c|c|c|c|c|c|c|}
\hline \multirow{2}{*}{$\begin{array}{c}\text { YEREL ZEMIN } \\
\text { SINIFI }\end{array}$} & \multicolumn{7}{|c|}{$\mathbf{1 , 0}$ saniye periyot için Yerel Zemin Etki Katsayısı $\boldsymbol{F}_{\boldsymbol{l}}$} \\
\cline { 2 - 7 } & $S_{l} \leq 0,10$ & $S_{l}=0,20$ & $S_{l}=0,30$ & $S_{l}=0,40$ & $S_{l}=0,50$ & $S_{l} \geq 0,60$ \\
\hline ZA & 0,8 & 0,8 & 0,8 & 0,8 & 0,8 & 0,8 \\
\hline ZB & 0,8 & 0,8 & 0,8 & 0,8 & 0,8 & 0,8 \\
\hline ZC & 1,5 & 1,5 & 1,5 & 1,5 & 1,5 & 1,4 \\
\hline ZD & 2,4 & 2,2 & 2,0 & 1,9 & 1,8 & 1,7 \\
\hline ZE & 4,2 & 3,3 & 2,8 & 2,4 & 2,2 & 2,0 \\
\hline ZF & \multicolumn{7}{|c|}{ Sahaya özel zemin davraniş analizi yapilacaktır. } \\
\hline
\end{tabular}

Eşitlik 35'de tanımlanan Bina Önem Katsayısı (I) Çizelge 27'de Bina Kullanım Sınıfı ile birlikte verilmiştir.

Çizelge 27. Bina Kullanım Sinıfları ve Bina Önem Katsayısı (TBDY-2018)

Table 27. Building Using Classes and Building Important Factor (TBDY-2018)

\begin{tabular}{|c|c|c|}
\hline $\begin{array}{l}\text { Bina } \\
\text { Kullanım } \\
\text { Sinıfı }\end{array}$ & Binanın Kullanım Amacı & $\begin{array}{l}\text { Bina Önem } \\
\text { Katsayıs1 } \\
\text { (I) }\end{array}$ \\
\hline $\mathrm{BKS}=1$ & $\begin{array}{l}\text { - Deprem sonrası hemen kullanılması gerekli binalar (Hastane, } \\
\text { dispanser, sağlık ocağı, itfaiye binası, PTT ve diğer haberleşme } \\
\text { tesisleri gibi) } \\
\text { - Okullar, diğer eğitim bina ve tesisleri, yurtlar ve yatakhaneler, } \\
\text { askeri kışlalar, cezaevleri gibi) } \\
\text { - Müzeler } \\
\text { - Toksik patlayıcı, parlayıcı vb. özellikleri olan maddelerin } \\
\text { bulunduğu veya depolandı̆̆ı binalar }\end{array}$ & 1,5 \\
\hline $\mathrm{BKS}=2$ & $\begin{array}{l}\text { İnsanların kısa süreli ve yoğun olarak bulunduğu binalar (Alışveriş } \\
\text { merkezleri, spor tesisleri, sinema, tiyatro, konser salonları, } \\
\text { ibadethaneler gibi) }\end{array}$ & 1,2 \\
\hline $\mathrm{BKS}=3$ & $\begin{array}{l}\text { Yukarıdaki tanımlara dâhil olmayan binalar (Konutlar, işyerleri, } \\
\text { oteller, bina türü endüstri yapılar gibi) }\end{array}$ & 1,0 \\
\hline
\end{tabular}

Kısa periyot tasarım spektral ivme katsayısına bağlı olarak yapıların Deprem Tasarım Sınıfları ise Çizelge 28' de verilmiştir. 
Çizelge 28. Deprem Tasarım Sinıfları (DTS) (TBDY-2018) Table 28. Seismic Design Classes (TBDY-2018)

\begin{tabular}{|c|c|c|}
\hline \multicolumn{2}{|c|}{ Table 28. Seismic Design Classes (TBDY-2018) } \\
\hline $\begin{array}{c}\text { Kisa periyot Tasarım } \\
\text { Spektral İvme Katsayısı } \\
\left(\boldsymbol{S}_{\boldsymbol{D S}}\right)\end{array}$ & \multicolumn{2}{|c|}{ Bina Kullanım Sınıfı } \\
\cline { 2 - 3 } & BKS=1 & BKS=2,3 \\
\hline$S_{D S}<0,333$ & DTS=4a & DTS=4 \\
\hline $0,333 \leq S_{D S}<0,667$ & DTS=3a & DTS=3 \\
\hline $0,667 \leq S_{D S}<1,00$ & DTS=2a & DTS=2 \\
\hline $1,00 \leq S_{D S}$ & DTS $=1 \mathrm{a}$ & DTS=1 \\
\hline
\end{tabular}

Eşitlik 35' de tanımlanan $S_{a R}(T)$ değeri aşağıdaki gibi hesaplanmaktadır.

$S_{a R}(T)=\frac{S_{a e}(T)}{R_{a}(T)}$

Burada $R_{a}(T)$ deprem yükü azaltma katsayısını ifade etmektedir. Eşitlik 48 ve 49 ile hesaplanmaktadir.

$$
\begin{array}{ll}
R_{a}(T)=\frac{R}{I} & T>T_{B} \\
R_{a}(T)=D+\left(\frac{R}{I}-D\right) \frac{T}{T_{B}} & T \leq T_{B}
\end{array}
$$

Burada R, Taşıyıcı Sistem Davranış Katsayısını, D Dayanım Fazlalığı Katsayısını, I Bina Önem Katsayısını ifade etmektedir. $\mathrm{R}$ ve $\mathrm{D}$ değerleri Çizelge 30 'da verilmiştir. 
Çizelge 29. Taşıyıcı Sistem Davranış Katsayıları ve Dayanım Fazlalığı Katsayıları (TBDY-2018) Table 29. Load Bearing System Behavior Factor and Overstrength Factor (TBDY-2018)

\begin{tabular}{|c|c|c|}
\hline Bina Taşıyıcı Sistemi & $\begin{array}{l}\text { Taşıyıcı Sistem } \\
\text { Davranış } \\
\text { Katsayısı R }\end{array}$ & $\begin{array}{l}\text { Dayanım } \\
\text { Fazlalı̆̆ı } \\
\text { Katsayısı D }\end{array}$ \\
\hline \multicolumn{3}{|c|}{ A. YERİNDE DÖKME BETONARME BİNA TAŞIYICI SİSTEMLERİ } \\
\hline \multicolumn{3}{|c|}{ A1. Süneklik Düzeyi Yüksek Taşıyıcı Sistemler } \\
\hline $\begin{array}{l}\text { A11. Deprem etkilerinin tamamının moment aktaran süneklik } \\
\text { düzeyi yüksek betonarme çerçevelerle karşılandığı binalar }\end{array}$ & 8 & 3 \\
\hline $\begin{array}{l}\text { A12. Deprem etkilerinin tamamının süneklik düzeyi yüksek bağ } \\
\text { kirişli (boşluklu) betonarme perdelerle karşılandığı binalar }\end{array}$ & 7 & 2,5 \\
\hline $\begin{array}{l}\text { A13. Deprem etkilerinin tamamının süneklik düzeyi yüksek } \\
\text { boşluksuz betonarme perdelerle karşılandığı binalar }\end{array}$ & 6 & 2,5 \\
\hline $\begin{array}{l}\text { A14. Deprem etkilerinin moment aktaran süneklik düzeyi yüksek } \\
\text { betonarme çerçeveler ile süneklik düzeyi yüksek bağ kirişli } \\
\text { (boşluklu) betonarme perdeler tarafından birlikte karşılandığı } \\
\text { binalar }\end{array}$ & 8 & 2,5 \\
\hline $\begin{array}{l}\text { A15. Deprem etkilerinin moment aktaran süneklik düzeyi yüksek } \\
\text { betonarme çerçeveler ile süneklik düzeyi yüksek boşluksuz } \\
\text { betonarme perdeler tarafından birlikte karşılandığı binalar }\end{array}$ & 7 & 2,5 \\
\hline $\begin{array}{l}\text { A16. Deprem etkilerinin tamamının çatı düzeyindeki bağlantıları } \\
\text { mafsallı olan yüksekliği } 12 \text { m'yi geçmeyen süneklik düzeyi yüksek } \\
\text { betonarme kolonlar tarafından karşılandığı tek katlı binalar }\end{array}$ & 3 & 2 \\
\hline \multicolumn{3}{|l|}{ A2. Süneklik Düzeyi Sınırlı Taşıyıcı Sistemler } \\
\hline $\begin{array}{l}\text { A21. Deprem etkilerinin tamamının moment aktaran süneklik } \\
\text { düzeyi sinırlı betonarme çerçevelerle karşılandığı binalar }\end{array}$ & 4 & 2,5 \\
\hline $\begin{array}{l}\text { A22. Deprem etkilerinin tamamının süneklik düzeyi sınırlı } \\
\text { boşluksuz betonarme perdelerle karşılandığı binalar }\end{array}$ & 4 & 2 \\
\hline $\begin{array}{l}\text { A23. Deprem etkilerinin moment aktaran süneklik düzeyi sınırlı } \\
\text { betonarme çerçeveler ile süneklik düzeyi sınırlı boşluksuz } \\
\text { betonarme perdeler tarafından birlikte karşılandığı binalar }\end{array}$ & 4 & 2 \\
\hline \multicolumn{3}{|l|}{ A3. Süneklik Düzeyi Karma Taşıyıcı Sistemler } \\
\hline $\begin{array}{l}\text { A31. Deprem etkilerinin moment aktaran süneklik düzeyi sınırlı } \\
\text { betonarme çerçeveler ile süneklik düzeyi yüksek bağ kirişli } \\
\text { (boşluklu) betonarme perdeler tarafından birlikte karşılandığı } \\
\text { binalar }\end{array}$ & 6 & 2,5 \\
\hline $\begin{array}{l}\text { A32. Deprem etkilerinin moment aktaran süneklik düzeyi sınırlı } \\
\text { betonarme çerçeveler ile süneklik düzeyi yüksek boşluksuz } \\
\text { betonarme perdeler tarafından birlikte karşılandığı binalar }\end{array}$ & 5 & 2,5 \\
\hline $\begin{array}{l}\text { A33. Deprem etkilerinin moment aktaran süneklik düzeyi sınırlı } \\
\text { dolgulu (asmolen) veya dolgusuz tek doğrultulu dişli döşemeli } \\
\text { betonarme çerçeveler ile süneklik düzeyi yüksek bağ kirişli } \\
\text { (boşluklu) betonarme perdeler tarafından birlikte karşılandığ1 } \\
\text { binalar }\end{array}$ & 6 & 2,5 \\
\hline $\begin{array}{l}\text { A34. Deprem etkilerinin moment aktaran süneklik düzeyi sınırlı } \\
\text { dolgulu (asmolen) dişli döşemeli betonarme çerçeveler ile süneklik } \\
\text { düzeyi yüksek boşluksuz betonarme perdeler tarafından birlikte } \\
\text { karşılandığı binalar }\end{array}$ & 5 & 2,5 \\
\hline
\end{tabular}

Yerel zemin sınıflarının belirlendiği özellikler Çizelge 30'da verilmiştir. 
Çizelge 30. Zemin Sınıfları (TBDY - 2018)

Table 30. Soil classes (TBDY - 2018)

\begin{tabular}{|c|c|c|c|c|}
\hline \multirow{2}{*}{$\begin{array}{c}\text { Yerel } \\
\text { Zemin } \\
\text { Sinıfı }\end{array}$} & \multirow[b]{2}{*}{ Zemin Cinsi } & \multicolumn{3}{|c|}{ Üst 30 metrede ortalama } \\
\hline & & $\begin{array}{l}\left(V_{s}\right)_{30} \\
(m / s)\end{array}$ & $\begin{array}{c}\left(N_{60}\right)_{30} \\
(\text { darbe } / 30 \mathrm{~cm})\end{array}$ & $\begin{array}{l}\left(c_{u}\right)_{30} \\
(k P a)\end{array}$ \\
\hline ZA & Sağlam, sert kayalar & $>1500$ & - & - \\
\hline ZB & Az ayrışmış, orta sağlam kayalar & $760-1500$ & - & - \\
\hline $\mathrm{ZC}$ & $\begin{array}{l}\text { Çok sıkı kum, çakıl ve sert kil tabakaları veya } \\
\text { ayrışmış, çok çatlaklı zayıf kayalar }\end{array}$ & $360-760$ & $>50$ & $>250$ \\
\hline ZD & $\begin{array}{l}\text { Orta sıkı - sıkı kum, çakıl veya çok katı kil } \\
\text { tabakaları }\end{array}$ & $180-360$ & $15-50$ & $70-250$ \\
\hline ZE & $\begin{array}{l}\text { Gevşek kum, çakıl veya yumuşak - katı kil } \\
\text { tabakaları veya PI }>20 \text { ve } \mathrm{w}>\% 40 \text { koşullarını } \\
\text { sağlayan toplamda } 3 \text { metreden daha kalın } \\
\text { yumuşak kil tabakası }\left(c_{u}<250 \mathrm{kPa}\right) \text { içeren } \\
\text { profiller }\end{array}$ & $<180$ & $<15$ & $<70$ \\
\hline ZF & \multicolumn{4}{|c|}{$\begin{array}{l}\text { Sahaya özel araştırma ve değerlendirme gerektiren zeminler: } \\
\text { - Deprem etkisi altında çökme ve potansiyel göçme riskine sahip zeminler (sıvılaşabilir } \\
\text { zeminler, yüksek derecede hassas killer, göçebilir zayıf çimentolu zeminler) } \\
\text { - Toplam kalınlığı } 3 \text { metreden fazla turba ve/veya organik içeriği yüksek killer } \\
\text { - Toplam kalınlığ } 8 \text { metreden fazla olan yüksek plastisiteli (PI>50) killer } \\
\text { - Çok kalın (>35 m) yumuşak veya orta katı killer }\end{array}$} \\
\hline
\end{tabular}

\section{ARAŞTIRMA BULGULARI VE TARTIŞMA (RESEARCH OUTCOMES and DISCUSSIONS)}

Eşdeğer deprem yükü metotlarının karşılaştırılabilmesi ETABS programı kullanılarak $\mathrm{x}$ ve $\mathrm{y}$ yönlerinde iki açıklığa sahip açıklıkları 3 m olan, kat yüksekliği $3 \mathrm{~m}$ olan ve 6 kattan oluşan bir bina modellenmiştir (Şekil 7). Yapı kolon ve kirişlerden oluşan çerçeve bir sistem olarak modellenmiştir. Döşemeler shell (kabuk) eleman olarak modellenmiştir. Kolonların tabana ankastre olarak bağlandığı kabul edilmiştir. Yapının kat planı ise şekil $8^{\prime}$ de verilmiştir. Yapının modellenmesinde beton birim hacim ağırlı̆̆ $2,40 \mathrm{kN} / \mathrm{m}^{3}$, döşemelere etki eden hareketli yük $5 \mathrm{kN} / \mathrm{m}^{2}$, döşemelere etki eden ilave ölü yük $1,50 \mathrm{kN} / \mathrm{m}^{2}$, ve kiriş üzerine ise duvar yükü olarak $6,25 \mathrm{kN} / \mathrm{m}^{2}$ olarak tanımlanmıştır. Yapılan analiz sonucu yapının deprem hesabına esas ağırlı̆̆ının 4217,61 kN olduğu bulunmuştur. Analiz sonucunda yapının birinci doğal titreşim periyodunun ise $0,4384 \mathrm{~s}$ olduğu belirlenmiştir. Yapının radye temeller üzerine oturduğu düşünülmüştür. Kullanım amacı olarak okul kabul edilmiştir. Yapının bulunduğu yer ise hem zemin açısından hem deprem bölgesi açısından hangi yönetmeliğe göre hesap yapılacak ise o yönetmeliğin maksimum koşullarını veren bölge olarak seçilmiştir. Yapının taşıyıcı sistem türü çerçeve, süneklik düzeyi ise normal ya da sınırlandırılmış olarak kabul edilmiştir. Yapı yerinde dökme betonarme bir yapıdır. 
Çizelge 31. Eşdeğer deprem yükü hesabında kullanılacak değerler Table 31. Values used in equivalent lateral load analysis

\begin{tabular}{|c|c|c|c|c|c|c|c|}
\hline & IS 1893 & $\begin{array}{c}\text { NZS } \\
4203: 1192\end{array}$ & EAK2000 & $\begin{array}{c}\text { STANDARD } \\
2800\end{array}$ & $\begin{array}{c}\text { EUROCODE - } \\
8\end{array}$ & \multicolumn{2}{|c|}{ TBDY - 2018} \\
\hline $\begin{array}{l}\text { Yapinın } \\
\text { Ağırlığ }(k N)\end{array}$ & 4217,61 & 4217,61 & 4217,61 & 4217,61 & 4217,61 & \multicolumn{2}{|c|}{4217,61} \\
\hline $\begin{array}{l}\text { Yap1 Önem } \\
\text { Katsayıs1 }\end{array}$ & 1,50 & 1,20 & 1,15 & 1,20 & 1,20 & \multicolumn{2}{|c|}{1,50} \\
\hline $\begin{array}{l}\text { Deprem } \\
\text { Bölge } \\
\text { Katsayısı }\end{array}$ & 0,36 & 0,8 & 0,36 & 0,35 & 0,48 & $\begin{array}{l}S_{D S} \\
=1,564\end{array}$ & $\begin{array}{l}S_{D l} \\
=1,145\end{array}$ \\
\hline $\begin{array}{l}\text { Taşıyıcı } \\
\text { Sistem } \\
\text { Davranış } \\
\text { Katsayısı } \\
\end{array}$ & 3,0 & 3,0 & 3,50 & 4,0 & $3,0 \cdot\left(\alpha_{0} / \alpha_{1}\right)^{1}$ & \multicolumn{2}{|c|}{4,0} \\
\hline Zemin Sinufi & $\begin{array}{c}\text { Tip } 3 \\
(0,10 \leq \mathrm{T} \leq \\
0,67)\end{array}$ & $\begin{array}{c}\text { Orta } \\
\text { zeminler }\end{array}$ & $\begin{array}{c}\Delta \\
(0,20 \leq \mathrm{T} \leq \\
1,20)\end{array}$ & $\begin{array}{c}\text { IV } \\
(0,15 \leq \mathrm{T} \leq \\
1,00)\end{array}$ & $\begin{array}{c}\mathrm{D} \\
(0,20 \leq \mathrm{T} \leq \\
0,80)\end{array}$ & \multicolumn{2}{|c|}{ ZE } \\
\hline $\begin{array}{l}\text { Deprem } \\
\text { İvme } \\
\text { Katsayısı }\end{array}$ & 2,50 & 0,38 & - & 1,75 & 1,35 & \multicolumn{2}{|c|}{2,72} \\
\hline $\begin{array}{l}\text { Yapi Risk } \\
\text { Durumu }\end{array}$ & - & 1,20 & - & - & - & \multicolumn{2}{|c|}{ - } \\
\hline $\begin{array}{l}\text { Sinir Durum } \\
\text { Katsayıs }\end{array}$ & - & 1,0 & - & - & - & \multicolumn{2}{|c|}{-} \\
\hline $\begin{array}{l}\text { Temel } \\
\text { Katsayıs1 }\end{array}$ & - & - & 0,90 & - & - & \multicolumn{2}{|c|}{ - } \\
\hline $\begin{array}{l}\text { Sönüm } \\
\text { Oranı }\end{array}$ & - & - & $\% 5$ & - & - & \multicolumn{2}{|c|}{-} \\
\hline
\end{tabular}

${ }^{1} \alpha_{0} / \alpha_{1}=1,30$ (çok katlı çok açıklıklı yapılar için)

${ }^{2}$ Doğal titreşim periyodu $0,4384 \mathrm{~s}$ olduğu için zemin sınıfi orta zemin seçilmiş̧tir. Esnek zeminler seçilememektedir.

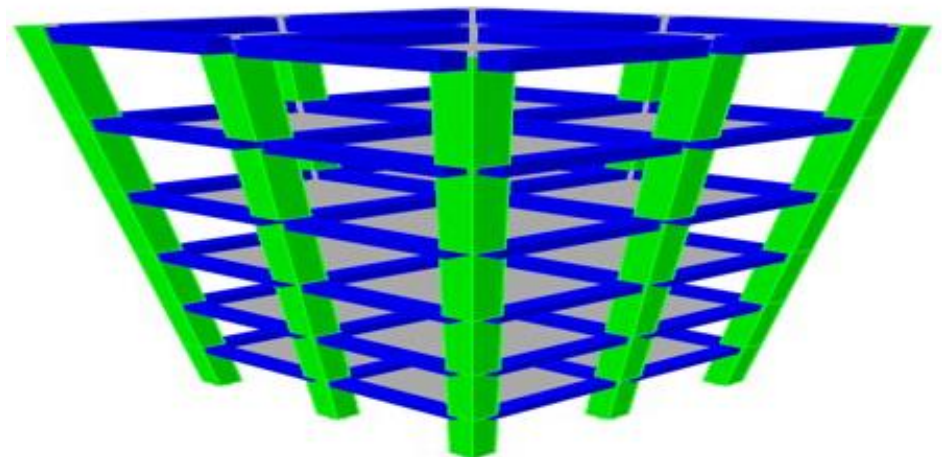

Şekil 7. Yapının 3D modeli

Figure 7. 3D model of the building 


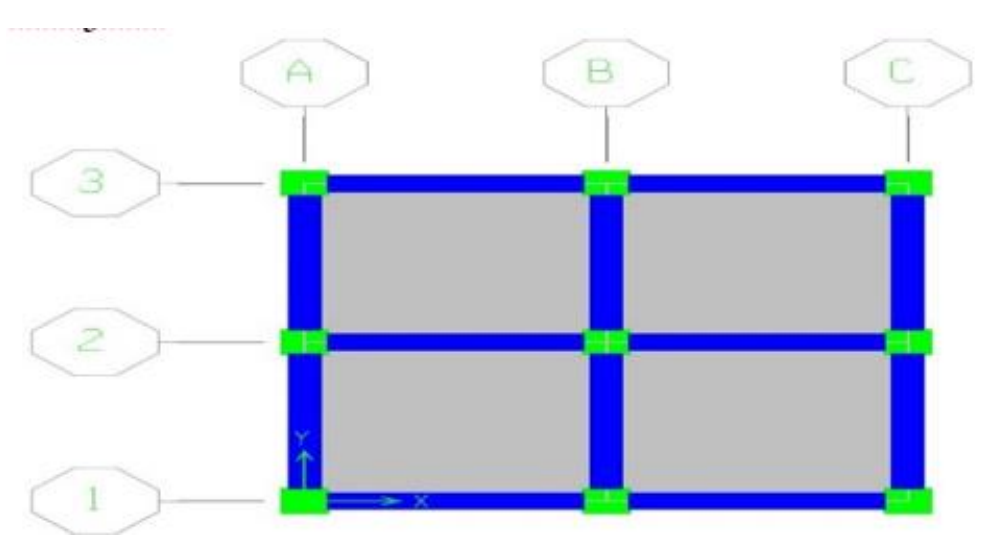

Şekil 8. Yapı kat planı

Figure 8. Structural layout

\section{SONUÇLAR VE ÖNERILER (CONCLUSIONS AND SUGGESTIONS)}

Deprem hareketi anlaşılması ve hesaplanması zor karmaşık bir hareket olduğu için hesaplamaları kolaylaştırıcı farklı yöntemler geliştirilmiştir. Bu yöntemlerden biri olan Eşdeğer Deprem Yükü Metodu ise farklı ülkelerde farklı katsayılar kullanılarak uygulanmaktadır. Görülmektedir ki her ülkede yapılan analizlerde kullanılan katsayılar birbirinden farklı olmaktadır. Kullanılan katsayılar deprem etkisini deprem etkisinin hesabını kolaylaştırıcı katsayılar olduğu için gerçeklikte tam olarak yansıtılamamaktadır. Her ülkede kullanılan katsayıların birbirinden farklı olması da yine bu katsayıların kabuller doğrultusunda ortaya çıkmış olmasından kaynaklanmaktadır.

Her ülke yönetmeliği için hesaplanmış olan taban kesme kuvvetleri Çizelge 32' de verilmiştir.

Çizelge 32. Taban kesme kuvvetleri

Table 32. Base shear values

\begin{tabular}{|c|c|c|}
\hline $\begin{array}{c}\text { HESAP YAPILAN } \\
\text { YÖNETMELİK }\end{array}$ & $\begin{array}{c}\text { AíT OLDUĞU } \\
\text { ÜLKE }\end{array}$ & $\begin{array}{c}\text { TABAN KESME KUVVETI } \\
(\mathbf{k N )}\end{array}$ \\
\hline IS 1893 & HİNDİSTAN & 948,96 \\
\hline NZS 4203:1992 & YENİ ZELLANDA & 1476,23 \\
\hline EAK2000 & YUNANİSTAN & 1122,49 \\
\hline STANDARD 2800 & İRAN & 1217,84 \\
\hline EUROCODE - & AVRUPA & 1751,93 \\
\hline TBDY -2018 & TÜRKIYY & 1169,41 \\
\hline
\end{tabular}

Grafik halinde sonuçlar Şekil 9'da verilmiştir. 


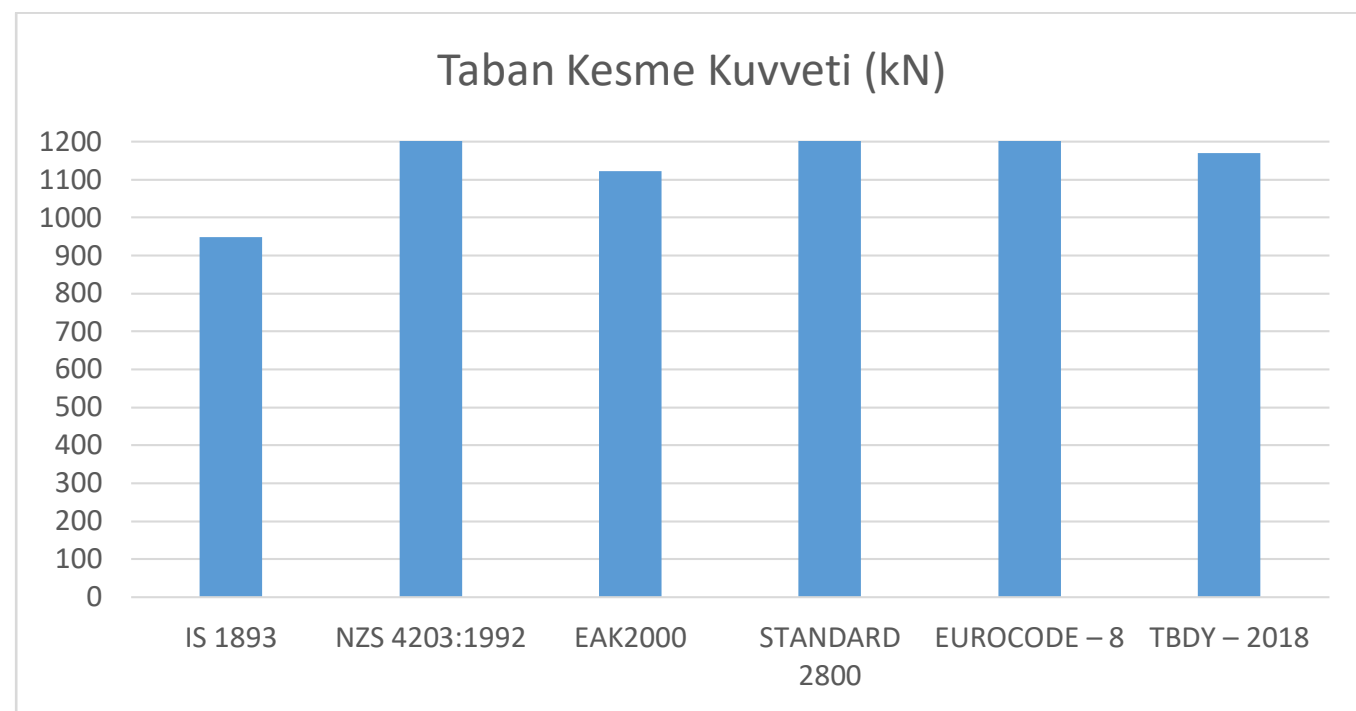

Şekil 9. Taban kesme kuvvetleri

Figure 9. Base shear forces

Çizelgede görüldüğü gibi en düşük deprem kuvveti Hindistan yönetmeliğinden elde edilirken en yüksek deprem kuvveti ise Eurocode $-8^{\prime}$ de elde edilmiştir. Ülkemizin yönetmelik kriterleri kullanılarak hesaplanan deprem kuvveti ise arada bir değer vermektedir. Ülkemiz sonuçlarına en yakın sonuçlar Yunanistan yönetmeliği kullanılarak elde edilen sonuçlardır.

Yapılan incelemeler neticesinde ülkemizde alınan bina önem katsayıları genel olarak diğer ülkelere göre yüksek değerlerdir. Yeni kriterler sayesinde Yapı davranış katsayısı, yapı sınıfına, yüksekliğine ve bulunduğu bölgeye göre detaylı olarak elde edilmektedir. Bölgelere ve yapı yüksekliğine göre kullanılabilecek taşıyıcı sistem türleri sınırlandırılmıştır. Yapılara etki edecek deprem ivmesinin hesap edilmesi için geliştirilen program sayesinde yapının koordinatları girilerek faya uzaklık ve buna bağlı olarak deprem ivme katsayıları elde edilebilmektedir. Bu da keskin hatlar ile ayrılmış bir haritadan ziyade faya uzaklık sayesinde yapıya etki edebilecek deprem kuvvetinin daha doğru bir şekilde hesaplanmasına olanak sunmaktadir.

Genel anlamıla ülkemiz yönetmeliğinde yer alan katsayılar sonucu elde edilen taban kesme kuvvetleri diğer ülkeler ile yaklaşık sonuçlar vermektedir. Ancak yönetmeliğimizde tanımlanan katsayılar diğer yönetmeliklere göre daha hassas ve daha detaylı sonuçlar elde etmeye olanak sağlamaktadır. Bu katsayıların detaylandırılması sayesinde Eşdeğer Deprem Yükü yöntemi ile elde edilecek sonuçların diğer deprem hesap yöntemlerine yaklaşacağı düşünülmektedir.

\section{KAYNAKLAR (REFERENCES)}

Celep Z. ve Kumbasar N., 2000, Deprem Mühendisliğine Giriş ve Depreme Dayanıklı Yapı Tasarımı, Beta Dağıtım, İstanbul.

Deprem Bölgelerinde Yapılacak Yapılar Hakkında Yönetmelik, 2007, Bayındırlık ve İskan Bakanlığı̆, Ankara.

EAK2000: Greek Code For Seismic Resistant Structures, 2000, Environment Planning And Public Works, Athens.

Eurocode - 8: Design Of Structures For Earthquake Resistance - Part1 :General Rules, Seismic Actions And Rules For Buildings, 2004, European Commitee For Standardization, Brussels.

IS 1893 - 1:Criteria For Earthquake Resistant Design Of Structures, Part 1: General Provisions And Buildings, 2002, Boreau Of Indian Standards, New Delhi.

Küçük, D., 2006, Deprem zararlarını azaltma çalışmalarında mimarlık eğitiminin yeri, Yüksek Lisans Tezi, Gazi Üniversitesi, Fen Bilimleri Enstitüsü, Ankara, 148.

Naimi A., 2010, Türkiye ve İran Deprem Yönetmeliklerinin Eşdeğer Deprem Yükü Yöntemi Açısından 
Karşılaştırılması, Yüksek Lisans Tezi, KATÜ, Fen Bilimleri Enstitüsü, Trabzon.

NZS 4203:1992: General Structural Design And Design Loadings For Buildings, 1992, Stadards Association Of New Zealand, Wellington.

Standard 2800: Iranian Code Of Practice For Seismic Resistant Design Of Buildings,2007, Ministry Of Housing And Urban Development, Tehran.

Taşkın T., 2012, Çok Katlı Bir Betonarme Yapının Farklı Ülke Yönetmeliklerine Göre Tasarımı, Yüksek Lisans Tezi, İstanbul Teknik Üniversitesi, Fen Bilimleri Enstitüsü, İstanbul.

Tekince Ö., 2015, Betonarme Binalarda Doğrusal Analiz Yöntemlerinin TDY - 2007 ve EC - 8' e Göre Karşılaştırılması, Yüksek Lisans Tezi, İstanbul Teknik Üniversitesi, Fen Bilimleri Enstitüsü, İstanbul. Ünal A., 2012, TDY - 2007’ ye Göre Tasarlanmamış Betonarme Çerçevelerin Düzlem Dışı Perde

Duvarla Güçlendirilmesi, Yüksek Lisans Tezi, Selçuk Üniversitesi, Fen Bilimleri Enstitüsü, Konya 